\title{
Seasonal Changes of Nutrient Distributions along Selangor River, Malaysia
}

\author{
${ }^{*}$ Nobuyuki Kawasaki ${ }^{1,3}$, MRM Kushairi ${ }^{1}$, Norio Nagao ${ }^{2}$, Fatimah Yusoff ${ }^{2}$, Akio Imai ${ }^{3}$, \\ and Ayato Kohzu ${ }^{3}$
}

\begin{abstract}
Water samples were taken six times along Selangor River between January 2014 and May 2015 in order to estimate the nutrient changes in different seasons. In the upstream, the nutrient concentrations were higher during the wet period compared to the dry due to the nutrient loading from the eroded soils. Aquaculture ponds could also contribute to the nutrient elevation. Nearly $10 \%$ of the increased nutrients between two sampling stations could come from the aquaculture waste. The relatively high ammonia concentrations were observed in the lower part of Selangor River due to a significant input of ex-mining ponds water and one major arm river which flows through large towns. Our results showed the water quality of Selangor River is clean enough to be suitable for drinking water, but the further study of other parameters such as heavy metals is necessary to ensure the water quality of Selangor River.
\end{abstract}

Keywords-Selangor River, nutrient concentrations, dry and wet seasons, pollution sources

\section{INTRODUCTION}

Many tropical rivers in Southeast Asia have received serious concerns on eutrophication due to the recent rapid industrial and agricultural developments [1]. According to the Malaysia Department of Environment, there are about 139 river basins in Malaysia, and the water quality of these rivers has been monitored. Their reports suggested that the river water quality has been slightly improved [2], but due to the illegal dumping, insufficient sewage systems and inadequate pollution prevention activities, there are still many issues in terms of the river water quality in Malaysia.

Selangor River, which starts from Kuala Kubu Bharu in the east and comes out of the Straits of Malacca at Kuala Selangor in the west, is one of the most important rivers in Malaysia. It possesses two dams, Sungai Tinggi and Selangor dams, which support about $70 \%$ of drinking water supply in Kuala Lumpur metropolitan areas. It also has one of the largest firefly habitats in the world. Therefore, it is essential for us to protect and properly manage the river water quality of Selangor River. Despite its importance, the sources of pollutants as well as those fates, the seasonal changes of those inputs to the river are still largely unknown. According to the report by WWF Malaysia [3], the major pollution sources include poorly treated

\footnotetext{
${ }^{1 * N o b u y u k i ~ K a w a s a k i ~(c o r r e s p o n d i n g ~ a u t h o r) ~ \& ~ M R M ~ K u s h a i r i, ~ U n i v e r s i t i ~}$ Selangor, Malaysia,

${ }^{2}$ Fatimah Yusoff \& Norio Nagao, Universiti Putra Malaysia, Malaysia

${ }^{3}$ Akio Imai \& Ayato Kohzu, National Institute for Environmental Studies, Japan
}

or untreated sewage, siltration from land cleaning, construction, and sand mining activities, runoff from agriculture land, and untreated effluents from industries. The recent study showed that aquaculture ponds could be one of the major nutrient sources in Selangor River [4]. There are at least 300 freshwater and nearly 50 brackish aquaculture ponds along Selangor River, but their effects on the river water quality as well as the aquatic organisms remain unknown.

In this study, the river water samplings were conducted throughout Selangor River in both wet and dry periods between January 2014 and May 2015 in order to examine how the nutrient concentrations are changed as well as where the potential sources of nutrients are through Selangor River. The impacts of aquaculture ponds on the nutrient loadings to Selangor River were also elaborated, and this is the first study to estimate the impacts of aquaculture farms to the surrounding environments. Our results will provide the useful data to improve the pollutant prevention in Malaysian rivers.

\section{MATERIALS AND METHODS}

Samplings were conducted six times every two or three month between January 2014 and May 2015. Eight different sampling points along Selangor River and two points at one of arm rivers were selected as shown in Fig. 1. Water samples were collected by a bucket and pre-filtered by a $140-\mu \mathrm{m}$ mesh before being poured into 2-L Nalgene poly-carbonate bottles. The bottles were stored in a cooler. The water temperature, $\mathrm{pH}$, salinity, dissolved oxygen concentration, and conductivity were measured on site using a YSI multimeter. After coming back to University of Selangor (UNISEL), the water samples were filtered by GF/F filters (Whatman) with gentle vacuum. The filtrate was stored with a 60-mL HDPE bottle (Nalgene) in a freezer $\left(-30^{\circ} \mathrm{C}\right)$ until analyses.

During the samplings, we have experienced both dry and wet periods. The water samples during the dry periods were collected on the day when no rain was observed for at least previous three days, and the water level of the river was low. On the other hand, the water samples during the wet periods were collected when the significant amount of rain was observed for at least one day before the sampling, and the water level of the river was also high. The sampling during the dry periods was made in Feb 2014, May 2014, and Feb 2015, while the sampling during the wet periods was made in Jan 2014, Nov 2014 and May 2015. 


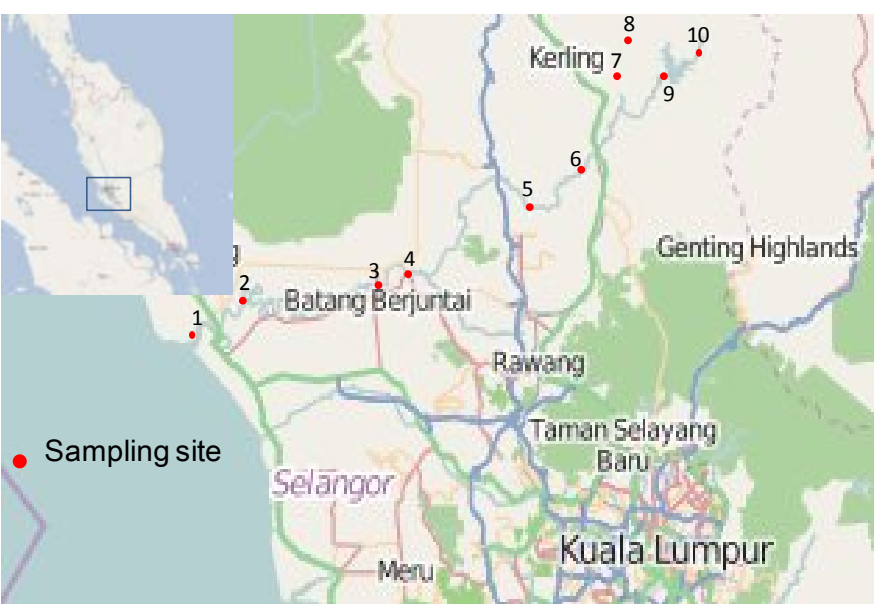

Fig. 1 Location map of Selangor River, Malaysia

Total dissolved nitrogen (TDN), total dissolved phosphorous (TDP), nitrate, ammonia and phosphate were measured for the nutrient analyses. TDN, nitrate, ammonia, TDP and phosphate were estimated using Lovibond MD-600 Photometer System (Tintometer GmbH, Germany) or a spectrophotometer (Shimadzu). The method using MD-600 and spectrophotometer is a colorimetric assay and each nutrient is reacted with specific chemical reagents which produce the specific color. The nutrient concentrations are positively correlated with the strength of color. Each nutrient was measured in triplicate and the average was calculated. The limit of detection of TDN, TDP, nitrate, ammonia and phosphate is $0.1 \mathrm{~N} \mathrm{mg} / \mathrm{L}, 0.001 \mathrm{P} \mathrm{mg} / \mathrm{L}$, $0.08 \mathrm{~N} \mathrm{mg} / \mathrm{L}, 0.02 \mathrm{~N} \mathrm{mg} / \mathrm{L}$, and $0.001 \mathrm{P} \mathrm{mg} / \mathrm{L}$, respectively. The coefficient variance (CV) of each measurement was usually less than $2 \%$.

\section{RESUlTS AND DISCUSSION}

\section{A. Physical Properties of River Water}

The physical parameters of the water conditions are shown in Table I. The water temperature ranged from 21.7 to $30.1^{\circ} \mathrm{C}$. The water temperature was generally low in upstream and high in downstream. The water temperature at St 9 was generally high $\left(26^{\circ} \mathrm{C}\right)$ because St 9 is located right after the water from the Selangor Dam was released. The dam water should be heated up during its stay in the dam.

The significant change of salinity was only observed at St 1 which is located about $3 \mathrm{~km}$ inland from the river mouth. During the high tide during the dry period, the high salinity was observed at St 1 . The $\mathrm{pH}$ was observed to be nearly neutral ranging from 6.9 to 8.5 throughout the samplings. When the salinity was high, $\mathrm{pH}$ was also slightly elevated.

The dissolved oxygen (DO) concentrations ranged from 3.7 to $7.7 \mathrm{mg} / \mathrm{L}$. The DO concentrations in Feb 2015 were not included because the values were significantly lower than those in other sampling occasions. This could be due to improper calibration of the DO meter in the YSI multimeter. The DO concentrations were generally high in upstream and low in downstream. The water with relatively low DO concentrations $(<5 \mathrm{mg} / \mathrm{L})$ at Sts 1 and 2 were categorized in Class III for National Water Quality for Malaysia. The Class III water usually requires an extreme treatment for drinking water, not suitable for drinking water source.

TABLE I

THE RANGES AND AVERAGES ( \pm SD) OF PHYSICAL PARAMETERS DURING 6 SAMPLINGS

\begin{tabular}{cccccc}
\hline Station & $\begin{array}{c}\text { Temperature } \\
\left({ }^{\circ} \mathrm{C}\right)\end{array}$ & $\begin{array}{c}\text { Salinity } \\
(\mathrm{ppt})\end{array}$ & $\mathrm{pH}$ & $\begin{array}{c}\text { Dissolved } \\
\text { Oxygen } \\
(\mathrm{mg} / \mathrm{L})^{1}\end{array}$ & Conductivity \\
\hline St1 & $26.9-30.0$ & $0.03-24.31$ & $7.4-8.3$ & $3.7-4.9$ & $0.23-42.68$ \\
& $(28.4 \pm 1.3)$ & $(7.72 \pm 9.62)$ & $(7.9 \pm 0.3)$ & $(4.5 \pm 0.5)$ & $(16.75 \pm 17.62)$ \\
St2 & $27.1-30.1$ & $0.02-0.23$ & $7.1-8.5$ & $4.1-5.2$ & $0.07-0.51$ \\
& $(28.2 \pm 1.3)$ & $(0.09 \pm 0.09)$ & $(7.7 \pm 0.05)$ & $(4.7 \pm 0.6)$ & $(0.24 \pm 0.21)$ \\
St3 & $25.9-27.1$ & $0.01-0.07$ & $7.2-7.9$ & $4.9-6.0$ & $0.05-0.15$ \\
& $(26.6 \pm 0.4)$ & $(0.03 \pm 0.02)$ & $(7.5 \pm 0.3)$ & $(5.4 \pm 0.5)$ & $(0.08 \pm 0.04)$ \\
St4 & $25.8-27.2$ & $0.01-0.04$ & $7.2-7.8$ & $4.5-6.4$ & $0.06-0.09$ \\
& $(26.5 \pm 0.5)$ & $(0.01 \pm 0.01)$ & $(7.4 \pm 0.2)$ & $(5.5 \pm 0.7)$ & $(0.07 \pm 0.01)$ \\
St5 & $25.0-26.1$ & 0 & $7.0-7.6$ & $5.2-7.4$ & $0.02-0.06$ \\
& $(25.5 \pm 0.4)$ & & $(7.4 \pm 0.2)$ & $(6.5 \pm 0.8)$ & $(0.04 \pm 0.02)$ \\
St6 & $24.7-26.0$ & 0 & $7.3-7.7$ & $6.0-7.6$ & $0.02-0.03$ \\
& $(25.3 \pm 0.5)$ & & $(7.4 \pm 0.1)$ & $(6.7 \pm 0.7)$ & $(0.02 \pm 0.01)$ \\
St7 & $24.1-25.5$ & 0 & $6.9-7.6$ & $5.9-7.3$ & $0.02-0.03$ \\
& $(24.9 \pm 0.5)$ & & $(7.3 \pm 0.2)$ & $(6.7 \pm 0.7)$ & $(0.02 \pm 0.01)$ \\
St8 & $22.0-23.7$ & 0 & $7.1-7.7$ & $6.2-7.5$ & $0.02-0.03$ \\
& $(23.1 \pm 0.6)$ & & $(7.4 \pm 0.2)$ & $(6.7 \pm 0.6)$ & $(0.02 \pm 0.01)$ \\
St9 & $25.4-27.0$ & 0 & $7.2-7.5$ & $5.9-7.6$ & $0.02-0.03$ \\
& $(26.1 \pm 0.6)$ & & $(7.3 \pm 0.1)$ & $(6.6 \pm 0.7)$ & $(0.02 \pm 0.01)$ \\
St10 & $21.7-23.3$ & 0 & $7.2-7.5$ & $6.0-7.7$ & $0.01-0.03$ \\
& $(22.6 \pm 0.5)$ & & $(7.3 \pm 0.1)$ & $(6.7 \pm 0.7)$ & $(0.02 \pm 0.01)$ \\
\hline
\end{tabular}

1: Dissolved oxygen concentration in Fe 2 low values were recorded compared to others.

\section{B. Nutrient Concentrations of River Water}

The nutrient concentrations are shown in Table II. All the nutrient concentrations were generally low in upstream and gradually increased towards downstream. The total dissolved nitrogen (TDN) concentrations ranged from 0.51 to $13.4 \mathrm{mg}$ $\mathrm{N} / \mathrm{L}$. The extremely high concentrations of TDN at Sts 1 and 2 (13.0 and $13.4 \mathrm{mg} \mathrm{N} / \mathrm{L}$, respectively) were observed during the sampling in Feb, 2015. This was due to the high tide which caused the high turbulence due to the mixture of fresh and marine water. The high water turbulence could result in the resuspension of sediment, which would release a significant amount of nutrients attached to the sediment into the river water.

Total dissolved phosphorus (TDP) concentrations ranged from 0.004 to $0.370 \mathrm{mg} \mathrm{P} / \mathrm{L}$. The TDP concentrations were correlated with the high TN concentrations during the sampling in Feb, 2015. The ammonia concentrations ranged from 0.01 to $0.98 \mathrm{mg} \mathrm{N} / \mathrm{L}$. The relatively high concentrations $(>0.7 \mathrm{mg}$ $\mathrm{N} / \mathrm{L}$ ) were observed at St 2 in Feb (0.81 mg N/L) and May 2015 (0.82 mg N/L), at St 3 in May 2014 (0.88 mg N/L), at St 4 in May 2014 (0.98 mg N/L), and at St 5 in Jan 2014 (0.77 mg N/L). According to the National Water Quality for Malaysia, the water including ammonia higher than $0.7 \mathrm{mg} \mathrm{N} / \mathrm{L}$ can be categorized in Class III water. Our results suggest that occasionally the water quality of Selangor River may not be suitable for drinking water source. The sources of high ammonia concentrations observed in Selangor River could come from the high turbulence of sediment during the high tide, municipal waste, aquaculture farms and ex-mining ponds. The high ammonia concentrations at St 2 were correlated with the high turbulence due to the high tide which caused resuspension of sediment. Around Sts 3 and 4, there were many ex-mining ponds. The mining ponds have been distributed in the middle of 
Selangor, and it is estimated that there are about 442 different ponds near Selangor River. According to Daniel and Kawasaki [5], some of mining ponds contain high concentrations of ammonia, contributing to the high concentration of ammonia in Sts 3 and 4 .

The high nitrate concentrations were found at St 1 (3.92 mg $\mathrm{N} / \mathrm{L}$ ) and St 2 (4.30 mg N/L) in Feb 2015. These high concentrations were also correlated with the high TN concentrations. Besides these values, most of the nitrate concentrations were relatively low $(<1 \mathrm{mg} \mathrm{N} / \mathrm{L})$ in Selangor River. The nitrite concentrations were generally low, but occasionally, relatively high concentrations of nitrite were observed. The highest concentration of nitrite $(0.21 \mathrm{mg} \mathrm{N} / \mathrm{L})$ was observed at St 1 in Feb 2015. This value could affect some of fish [6]. The phosphate concentrations were relatively low through Selangor River.

TABLE II

THE RANGES AND AVERAGES ( \pm SD) OF NUTRIENT CONCENTRATIONS DURING 6 SAMPLINGS

\begin{tabular}{|c|c|c|c|c|c|c|}
\hline Station & $\begin{array}{l}\text { TDN(mg N/L) } \\
\text { (Ave. } \pm \text { SD) }\end{array}$ & $\begin{array}{l}\text { TDP(mg P/L) } \\
\text { (Ave. } \pm \text { SD) }\end{array}$ & $\begin{array}{l}\text { Ammonia(mg N/L) } \\
\text { (Ave. } \pm \text { SD) }\end{array}$ & $\begin{array}{l}\text { Nitrate(mg N/L) } \\
\text { (Ave. } \pm \text { SD) }\end{array}$ & $\begin{array}{l}\text { Nitrite(mg N/L) } \\
\text { (Ave. } \pm \text { SD) }\end{array}$ & $\begin{array}{l}\text { Phosphate(mg N/L) } \\
\text { (Ave. } \pm \text { SD) }\end{array}$ \\
\hline St1 & $\begin{array}{l}2.64-13.00 \\
(6.18 \pm 4.1)\end{array}$ & $\begin{array}{c}0.011-0.280 \\
(0.119 \pm 0.105)\end{array}$ & $\begin{array}{c}0.01-0.50 \\
(0.26 \pm 0.19)\end{array}$ & $\begin{array}{c}0.25-3.92 \\
(1.54 \pm 1.40)\end{array}$ & $\begin{array}{c}0.000-0.210 \\
(0.045 \pm 0.086)\end{array}$ & $\begin{array}{c}0.009-0.092 \\
(0.071 \pm 0.060)\end{array}$ \\
\hline St2 & $\begin{array}{l}2.80-13.40 \\
(6.00 \pm 4.07)\end{array}$ & $\begin{array}{c}0.020-0.370 \\
(0.094 \pm 0.136)\end{array}$ & $\begin{array}{c}0.25-0.81 \\
(0.47 \pm 0.27)\end{array}$ & $\begin{array}{c}0.23-4.30 \\
(1.58 \pm 1.73)\end{array}$ & $\begin{array}{c}0.018-0.060 \\
(0.034 \pm 0.021)\end{array}$ & $\begin{array}{c}0.002-0.123 \\
(0.040 \pm 0.046)\end{array}$ \\
\hline St3 & $\begin{array}{l}1.90-4.60 \\
(2.75 \pm 0.97)\end{array}$ & $\begin{array}{c}0.014-0.060 \\
(0.033 \pm 0.018)\end{array}$ & $\begin{array}{c}0.29-0.88 \\
(0.53 \pm 0.20)\end{array}$ & $\begin{array}{c}0.13-1.11 \\
(0.56 \pm 0.37)\end{array}$ & $\begin{array}{c}0.012-0.070 \\
(0.038 \pm 0.025)\end{array}$ & $\begin{array}{c}0.004-0.028 \\
(0.015 \pm 0.008)\end{array}$ \\
\hline St4 & $\begin{array}{l}1.30-3.20 \\
(2.31 \pm 0.67)\end{array}$ & $\begin{array}{c}0.011-0.110 \\
(0.045 \pm 0.035)\end{array}$ & $\begin{array}{c}0.29-0.98 \\
(0.52 \pm 0.27)\end{array}$ & $\begin{array}{c}0.15-1.03 \\
(0.54-0.33)\end{array}$ & $\begin{array}{c}0.014-0.090 \\
(0.046 \pm 0.034)\end{array}$ & $\begin{array}{c}0.012-0.051 \\
(0.025 \pm 0.014)\end{array}$ \\
\hline St5 & $\begin{array}{c}1.98-2.70 \\
(2.25 \pm 0.31)\end{array}$ & $\begin{array}{c}0.014-0.150 \\
(0.065 \pm 0.052)\end{array}$ & $\begin{array}{c}0.15-0.77 \\
(0.35 \pm 0.23)\end{array}$ & $\begin{array}{c}0.09-0.31 \\
(0.19 \pm 0.09)\end{array}$ & $\begin{array}{c}0.000-0.080 \\
(0.020 \pm 0.032)\end{array}$ & $\begin{array}{c}0.012-0.033 \\
(0.018 \pm 0.008)\end{array}$ \\
\hline St6 & $\begin{array}{c}1.49-1.98 \\
(1.76 \pm 0.19)\end{array}$ & $\begin{array}{c}0.017-0.077 \\
(0.032 \pm 0.023)\end{array}$ & $\begin{array}{c}0.05-0.18 \\
(0.13 \pm 0.04)\end{array}$ & $\begin{array}{c}0.08-0.28 \\
(0.17 \pm 0.09)\end{array}$ & $\begin{array}{c}0.000-0.010 \\
(0.004 \pm 0.005)\end{array}$ & $\begin{array}{c}0.011-0.028 \\
(0.016 \pm 0.008)\end{array}$ \\
\hline St7 & $\begin{array}{c}0.88-1.89 \\
(1.34 \pm 0.40)\end{array}$ & $\begin{array}{c}0.009-0.017 \\
(0.014 \pm 0.003)\end{array}$ & $\begin{array}{c}0.04-0.15 \\
(0.11 \pm 0.04)\end{array}$ & $\begin{array}{c}0.08-0.16 \\
(0.11 \pm 0.03)\end{array}$ & $\begin{array}{c}0.000-0.004 \\
(0.002 \pm 0.002)\end{array}$ & $\begin{array}{c}0.004-0.008 \\
(0.005 \pm 0.002)\end{array}$ \\
\hline St8 & $\begin{array}{c}0.61-1.78 \\
(1.22 \pm 0.51)\end{array}$ & $\begin{array}{c}0.007-.0014 \\
(0.011 \pm 0.002)\end{array}$ & $\begin{array}{c}0.03-0.11 \\
(0.07 \pm 0.03)\end{array}$ & $\begin{array}{c}0.06-0.13 \\
(0.09 \pm 0.03)\end{array}$ & $\begin{array}{c}0.000-0.004 \\
(0.001 \pm 0.002)\end{array}$ & $\begin{array}{c}0.002-0.006 \\
(0.004 \pm 0.002)\end{array}$ \\
\hline St9 & $\begin{array}{c}0.83-2.20 \\
(1.38 \pm 0.52)\end{array}$ & $\begin{array}{c}0.007-0.016 \\
(0.011 \pm 0.004)\end{array}$ & $\begin{array}{c}0.03-0.12 \\
(0.07 \pm 0.04)\end{array}$ & $\begin{array}{c}0.07-0.21 \\
(0.11 \pm 0.06)\end{array}$ & $\begin{array}{c}0.000-0.008 \\
(0.004 \pm 0.004)\end{array}$ & $\begin{array}{c}0.003-0.009 \\
(0.005 \pm 0.002)\end{array}$ \\
\hline St10 & $\begin{array}{c}0.51-2.20 \\
(1.08 \pm 0.61)\end{array}$ & $\begin{array}{c}0.004-0.013 \\
(0.009 \pm 0.003)\end{array}$ & $\begin{array}{c}0.02-0.19 \\
(0.07 \pm 0.06)\end{array}$ & $\begin{array}{c}0.05-0.18 \\
(0.09 \pm 0.05)\end{array}$ & $\begin{array}{c}0.000-0.009 \\
(0.005 \pm 0.006)\end{array}$ & $\begin{array}{c}0.001-0.005 \\
(0.003 \pm 0.001)\end{array}$ \\
\hline
\end{tabular}

\section{Possible Sources of Nutrients at Different Sampling} Stations

The nutrient concentrations in upstream sampling points (St 7-10) were significantly different between the dry and wet periods. During the wet periods, the average total dissolved nitrogen (TDN) and total dissolved phosphorus (TDP) concentrations were $1.51( \pm 0.30) \mathrm{mg} \mathrm{N} / \mathrm{L}$ and $0.013( \pm 0.002)$ $\mathrm{mg} \mathrm{P} / \mathrm{L}$, respectively, while the TDN and TDP concentrations during the dry were $0.99( \pm 0.35) \mathrm{mg} \mathrm{N} / \mathrm{L}$ and $0.009( \pm 0.002)$ mg P/L, respectively (Fig. 2). Both TDN and TDP concentrations during the wet periods were significantly higher than those during the dry (two-sided t-test; $\mathrm{p}<0.005$ ). This may indicate that the major sources of nutrients in the upstream come from the erosion of soil during the event of heavy rain.

The river water goes through several small towns including Kuala Kubu Bharu and agricultural areas (mainly palm oil forests) where the municipal and agricultural wastes are introduced into the river. The elevation of nutrients was observed between St 7 or 9 and St 6. This nutrient elevation should be due to municipal and agricultural waste inputs, but it is difficult to differentiate the nutrient inputs from different sources.



Fig. 2 Total dissolved nitrogen (TDN) and total dissolved phosphorus (TPN) concentrations from St 7 to 10 between wet and dry periods

The further increase of nutrients was observed between St 5 and 6 where some aquaculture ponds are located. Between St. 5 and 6, there are about 80 aquaculture ponds based upon our interview with aquaculture managers and Google Map. According to Kawasaki et al. [4], 100-200 kg N and 10-15 kg P can be released from each pond per year. If we assume that all 80 aquaculture ponds release the nutrients at the same manner, and we are able to obtain the flow data of Selangor River, the contribution of aquaculture to the nutrient loadings to Selangor River should be estimated. The average annual flow of Selangor River is $12.6 \mathrm{~m}^{3} / \mathrm{s}$ at Rasa, an upstream flow point near St 6 [7]. Since the location of the flow measurement is not accurately between Sts 5 and 6, our estimation may contain 
some errors. However, the value should be close enough to represent the flow rate of Selangor River near Sts 5 and 6. The TDN and TDP concentrations increased from 1.76 to $2.25 \mathrm{mg}$ $\mathrm{N} / \mathrm{L}$ and 0.032 to $0.065 \mathrm{mg} \mathrm{P} / \mathrm{L}$, respectively from St 6 to 5 . If the increase remains constant throughout the year, the increased amount of nitrogen and phosphorus can be calculated to be 1.95 $\mathrm{x} 10^{5} \mathrm{~kg} \mathrm{~N}$ and $1.31 \times 10^{4} \mathrm{~kg}$ P, respectively between Sts 5 and 6 . The released nitrogen and phosphorus from aquaculture farms then can be calculated. They account for about $4-8 \%$ of the increased nitrogen and 6-9\% of the increased phosphorus between St 5 and 6. This indicates that aquaculture ponds could significantly contribute to the elevation of nutrients in Selangor River, since there are at least 300 more aquaculture ponds in Selangor River.

The slight increase of nutrients (TDN and TDP) as well as the significant increase of ammonia was observed between St 3 and 5. Between Sts 3 and 5, there were more aquaculture ponds, and there is one major arm river converged to Selangor River. The arm river flows into Rawang, the town over 120,000 people, which brings more nutrients including ammonia to Selangor River. There are also many ex-mining ponds, and some of them directly flow into Selangor River. According to Daniel and Kawasaki [5], some of ex-mining ponds contain high ammonia which directly flows into Selangor River. These sources can cause the elevation of nutrients, especially ammonia in Selangor River between Sts 3 and 5.

The nutrient concentrations were high at Sts 1 and 2 . Although there are municipal and agricultural inputs, the nutrient concentrations appear to be influenced significantly by the tides. Although St 2 is about $20 \mathrm{~km}$ away from the river mouth, the effects of the high tides were observed occasionally. The sediment in the bottom of Selangor River appears to contain a lot of nutrients which can be released into the water due to the high turbulence created by the tides.

Selangor River is an important river in Malaysia and its water quality remains relatively clean for drinking water during our study. However, the high input of nutrients occasionally due to the heavy rains and artificial inputs can degrade the water quality. Besides the municipal and agricultural impacts, aquaculture ponds can be also the major source of nutrients. It is also important to estimate other elements such as heavy metals to ensure the water quality of Selangor River.

\section{ACKNOWLEDGMENT}

The financial support is made by the Malaysia Ministry of Higer Education under Fundamental Research Grant Scheme (FRGS/1/2013/STWN01/UNISEL/02/1). Sampling was supported by a master student, Daniel Ramachandran, and numerous undergraduate students including Yuvalin Krishn A/P Krishnan, Nor Farihah Bt Muda, Muhammad Balqis Bin Azizul Rahim, Tulip Adzarlia Mohamad Adzali, Yaswini A/P Subramaniam, Vickneswary A/P Vadivelu and Fadzrina Dolhan. We also thank Yuki Imaizumi at Universiti Putra Malaysia for the support of nutrient analyses and science officers in local fishery districts for proving aquaculture information in Selangor River.

\section{REFERENCES}

[1] G. R. Lanza, "Accelerated eutrophication in the Mekong River watershed: hydropower development, climate change, and waterborne disease," in Eutrophication: causes, consequences and control, A. A. Ansari, S. S. Gill, G. R. Lanza, W. Rast, Eds. Springer Netherlands, 2010, pp. 373-386.

http://dx.doi.org/10.1007/978-90-481-9625-8_19

[2] Malaysia Environmental Quality Report, 2006, pp. 72.

[3] D. J. Ong. "Land use in the Selangor River," WWF Malaysia, pp. 49.

[4] N. Kawasaki, M. R. M. Kushairi, N. Nagao, F. Yusoff, A. Imai, A. and Kohzu, "Release of nitrogen and phosphorus from aquaculture farms to Selangor River, Malaysia,” Int'l. J. Envir. Sci. Devel. Vol. 7, pp. 113-116, February 2016.

http://dx.doi.org/10.7763/IJESD.2016.V7.751

[5] R. Daniel and N. Kawasaki. "The distribution of heavy metals and nutrients along Selangor River and its adjacent mining ponds, Malaysia," Submitted to International Conference on Advances in Environment, Agriculture \& Medical Sciences.

[6] H. Kroupova, J. Machova and Z. Svobodova, "Nitrite influence on fish: a review,” Vet. Med. - Czech Vol. 50, pp. 461-471, 2005.

[7] M. A. Fulazzaky, T. W. Seong and M. I. M. Maserin, "Assessment of water quality status for the Selangor Riverin Malaysia," Water Air Soil Pollut., Vol. 205, pp. 63-77, 2010.

http://dx.doi.org/10.1007/s11270-009-0056-2

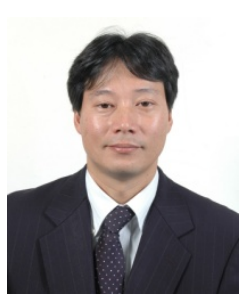

Nobuyuki Kawasaki was born in Osaka, Japan onMay 5, 1972. He has had a B.S. in bioengineering inFaculty of Engineering, the Department of Bioengineering, Soka University, Japan in 1995. Hehas had his M.S. degree majoring in biological oceanography at College of Oceanic and Atmospheric Sciences, Oregon State University, USA in 1999. He has had his PhD degree majoring in marine science at Marine Science Program, University of South Carolina, USA in 2006. He has worked at National Institute for Environmental Studies in Tsukuba, Japan as post-doc fellow between 2006 and 2011. Since 2011, he has been working at Faculty of Science and Biotechnology, Universiti Selangor, in Malaysia as a senior lecturer, and became an associate professor in March 2015. His current research interests include the water quality, microbiology, aquatic organic matter, aquatic elemental cycles, and size exclusion chromatography. Dr. Kawasaki is currently a member of American Society of Microbiology, Association for the Sciences of Limnology and Oceanography, Japan Society on Water Environment and Asia-Pacific Chemical, Biological\& Environmental Engineering Society. 